\title{
Fisheries catches and the carrying capacity of marine ecosystems in southern Brazil
}

\author{
Marcelo Vasconcellos ${ }^{\mathrm{a},{ }^{*},}$, Maria A. Gasalla ${ }^{\mathrm{b}}$ \\ ${ }^{a}$ Fisheries Centre, University of British Columbia, 2204 Main Mall, Vancouver, BC, Canada V6T 1Z4 \\ ${ }^{\mathrm{b}}$ Instituto de Pesca, Centro de Pesquisa Pesqueira Marinha, Av. Bartolomeu de Gusmão, 192, Santos, SP 11030-906, Brazil
}

Received 1 June 1999; received in revised form 24 February 2000; accepted 25 April 2000

\begin{abstract}
The carrying capacity of marine shelf ecosystems in southern Brazil for harvestable species is analyzed by (1) quantifying the amount of available primary production appropriated by fisheries catches, (2) evaluating the trend in the mean trophic level of fisheries, and (3) simulating the ecosystem effects of "fishing down the food web" in an intensively exploited shelf region. Fisheries utilize ca. 27 and 53\% of total primary production in the southern and south-eastern shelf regions, respectively. Regional variation in the carrying capacity appropriated by fisheries results from differences in the primary production, catch volume and trophic transfer efficiencies. Overall, fisheries landings do not display a trend of decreasing trophic level with time due to the collapse of the sardine fishery and the recent increasing of offshore fishing for higher trophic level species, mainly tunas and sharks. However, the simulations show that fishing down the food web through fisheries that target small pelagic planktivorous fishes, while at first increasing catches in intensively exploited regions, has the potential of decreasing yields, by interrupting major energy pathways to exploited, high-trophic level species. The consequences of these results to the design of precautionary measures for future fishing policies are discussed. (C) 2001 Elsevier Science B.V. All rights reserved.
\end{abstract}

Keywords: Carrying capacity; Shelf ecosystems; Trophic model; Marine fisheries; Brazil

\section{Introduction}

Recent assessments of the worldwide status of marine capture fisheries reveal alarming signs of human dominance and impact on the oceans. Fisheries alone appropriate ca. $8 \%$ of the total marine primary production and up to one-third of temperate continental shelf systems production (Pauly and Christensen, 1995). Over 60\% of the most important fish stocks are either overexploited or at the limit of becoming over-

\footnotetext{
${ }^{*}$ Corresponding author. Tel.: +1-604-822-1864; fax: +1-604-822-8934.

E-mail addresses: marcelo@fisheries.com (M. Vasconcellos), mgasalla@osite.com.br (M.A. Gasalla).
}

exploited by current fishing intensity (Garcia and Newton, 1997), and approximately 27 million $t$ of non-target animals are discarded annually as "trash" fish (Alverson et al., 1994). Also, present exploitation patterns are resulting in a "fishing down marine food webs" phenomenon, from long-lived, high-trophic level piscivorous fish to short-lived, low-trophic level invertebrates and planktivorous pelagic fishes (Pauly et al., 1998).

In line with some of these global trends, marine capture fisheries of Brazil are in a state of crisis caused by the scarcity of resources, over-capitalization of fisheries activities and the lack of sound fisheries management policies. At the same time, there are major efforts to assess the potential production of 
fishery resources in the Exclusive Economic Zone triggered by the country's ratification of the United Nations Convention on the Law of the Sea. Early assessments of the fisheries resources along the coast during the 1970s (Hempel, 1971; Neiva and Moura, 1977) indicated a potential total catch of over 1 million t per year, yet in fact, since the mid-1980s landings have stabilized around $700000 \mathrm{t}$ per year, and many of the traditional fish stocks have become either fully exploited or overexploited (Dias Neto, 1991a,b; IBAMA, 1994a-c; Reis et al., 1994; Cergole, 1995; Matsuura, 1995; Haimovici et al., 1997). This raises concerns as to whether the level of exploitation can be sustained without impairing the productivity and integrity of the marine ecosystems.
Brazil has an extensive coastline from $5^{\circ} \mathrm{N}$ to $34^{\circ} \mathrm{S}$, including regions of tropical and subtropical climate. Matsuura (1995) divided the Brazilian coast in five regions with distinct environmental characteristics and types of fishing activities (Fig. 1). In the north, biological production is high as a result of the continental runoff from the Amazon river (Teixeira and Tundisi, 1967). The wide continental shelf and the rich benthic community favor the development of trawling activities in this region, mostly for shrimps and large catfishes. The northeast and east regions are oligotrophic due to the influence of tropical waters from the Brazil Current. Rocky bottoms and a mostly narrow continental shelf induced the development of hookand-line fisheries for rockfishes, sharks and tunas. In

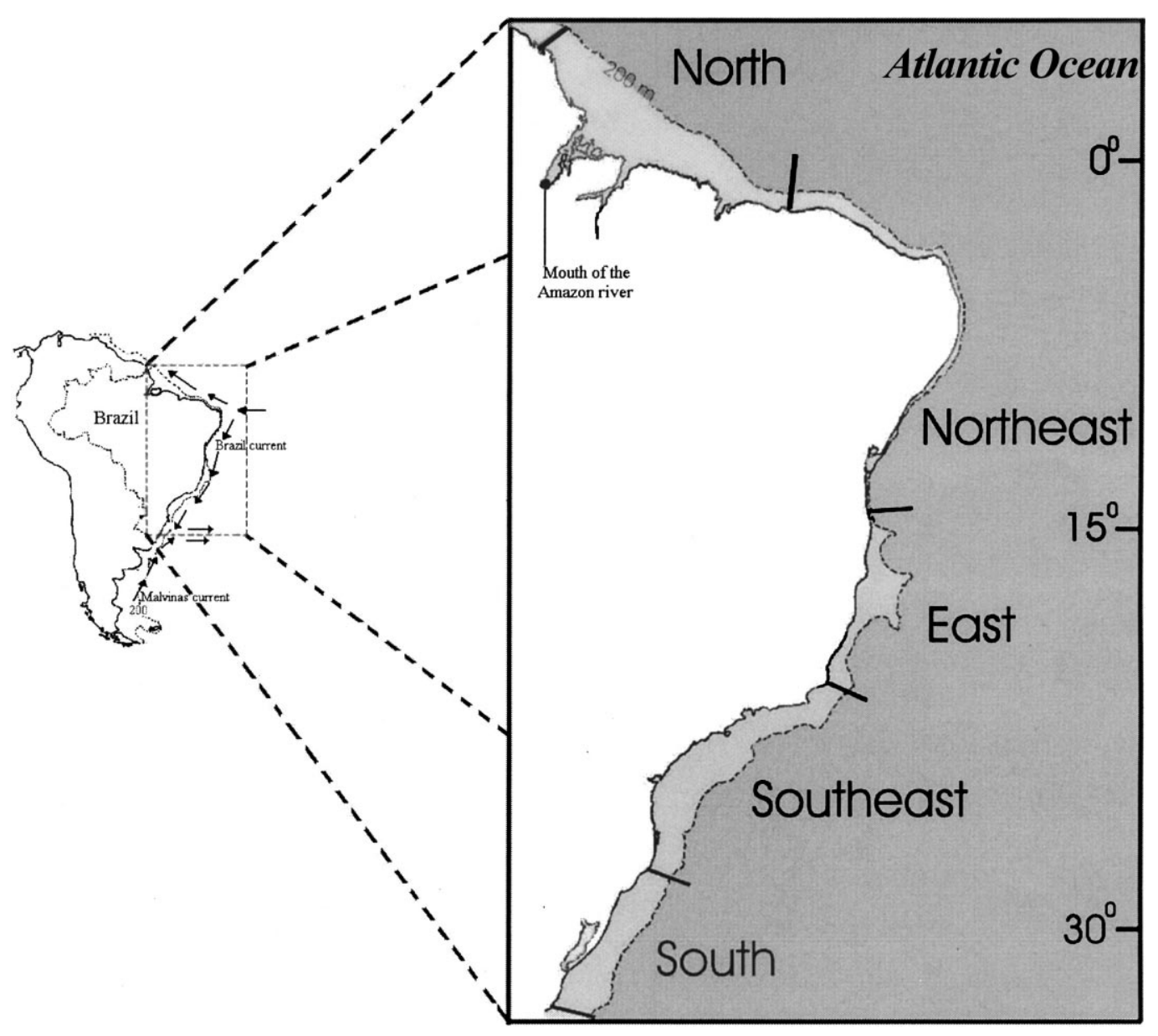

Fig. 1. Shelf regions of Brazil. Regions defined based on environmental characteristics and types of fishing activities, as suggested in Matsuura (1995). 
the southeast, primary production is mainly driven by seasonal upwelling of nutrient-rich, cold subtropical waters pumped by alongshore winds and by cyclonic vortexes originated from the Brazil Current (Bakun and Parrish, 1990; Matsuura, 1995). The southern part of the Brazilian coast is under the influence of the subtropical convergence between the southward and northward flowing Brazil and Malvinas Currents. The confluence of water masses and the high volume of continental runoff provide physical and chemical conditions for high biological production on the shelf (Seeliger et al., 1997). Trawling is the main type of fishing activity in the south-eastern and southern regions, although the presence of highly abundant pelagic stocks, mainly sardine, in the southeast has also lead to the development of an important purse seine fishery especially since 1950 .

The regions also differ in the type of fisheries production. While catches in the north, northeast and east regions are mainly from artisanal activities (Diegues, 1995), in the southern regions it is the industrial fisheries provide most of the landings, accounting for approximately half of the total Brazilian catches (IBAMA/IBGE, 1995). Historically, it was in the south and southeast that industrial fisheries were mostly developed through a series of government incentives, and this is where fisheries data are best documented.

This paper presents a comparative analysis of fisheries in the south-eastern and southern regions of Brazil which aims to assess the carrying capacity of the marine shelf ecosystems for harvestable species. Carrying capacity has been defined as the maximum size of a population or activity that could be indefinitely sustained without degrading the ecosystem's future productivity or suitability for that use (Odum, 1997). In the oceans, carrying capacity is usually referred to as the upper limit of biomass of organisms that can be supported by a set of primary production and food web structure (Christensen and Pauly, 1998). Fisheries yield is directly related to the carrying capacity of marine ecosystems, since there is a maximum sustainable rate of fish production associated with the total fish biomass at the carrying capacity. Fisheries can directly affect the carrying capacity of marine ecosystems by altering the structure of food webs and changing their potential productivity. Ecosystem carrying capacity is analyzed in three ways.
First by computing the total flux of energy, originated from primary producers, available to different trophic levels in the food web, and the total primary production required to sustain fisheries catches (Pauly and Christensen, 1995). The ratio of these two quantities provides a measure of the "appropriated carrying capacity" (sensu Rees, 1996) of ecosystems, i.e. the amount of the available energy in an ecosystem already appropriated by fisheries catches. Second, we present a diagnosis of fisheries for the "fishing down the food web" phenomenon using trophic level estimates and national and regional catch statistics. Third, the impact of fisheries on the structure of an exploited ecosystems is evaluated by simulating the effect of a "fishing down the food web" scenario in the southern shelf region, where traditional demersal fish stocks are overexploited and the prospects for increasing yield rely on exploiting abundant small pelagic forage fish.

\section{Methods}

The method used here to quantify the appropriated carrying capacity follows the approach developed by Pauly and Christensen (1995) for the analysis of primary production required to sustain world fisheries. Primary production required by fisheries (PPR) is estimated based on the trophic level of the species caught, the energy transfer efficiency between trophic levels, and on the primary productivity of the two shelf regions (Table 1). Primary production estimates for the southeast and south were obtained from Brandini (1990) and Odebrecht and Garcia (1997), respectively. Species trophic levels (Table 2) were computed according to Odum and Heald (1975) using available information on diet composition, and from trophic models. In this analysis, primary producers are trophic level 1, and each higher order consumers are trophic level 1 plus the weighted average trophic level of its preys. Rocha et al. (1998) constructed a trophic model of the Ubatuba region in the south-eastern shelf that is here used to calculate the mean trophic transfer efficiency for the region. Mean trophic transfer efficiency for the southern shelf is calculated from the trophic model described below. In these models, transfer efficiencies are calculated as the percentage of throughput entering a trophic level that is subse- 
Table 1

Area, primary productivity and total primary production of southern and south-eastern shelf regions of Brazil ${ }^{\mathrm{a}}$

\begin{tabular}{llllll}
\hline Region & Area $\left(\times 10^{10} \mathrm{~m}^{2}\right)$ & \multicolumn{2}{l}{$\mathrm{PP}\left(\mathrm{gC} \mathrm{m}^{-2}\right.$ per year $)$} & \multirow{2}{*}{$\begin{array}{l}\text { Total PP } \\
\left(10^{12} \mathrm{gC} \text { per year }\right)^{\mathrm{b}}\end{array}$} \\
\cline { 3 - 5 } & & Minimum & Likeliest & Maximum & 14.40 \\
\hline Southeast & 17.14 & 33 & 84 & 158 & 18.25 \\
South & 11.40 & 72 & 160 & 382 & \\
\hline
\end{tabular}

${ }^{\text {a }}$ Shelf areas were measured to the $200 \mathrm{~m}$ depth line using planimetry.

${ }^{\mathrm{b}}$ Based on the likeliest primary productivity.

Table 2

Trophic level of the main species landed in Brazil

\begin{tabular}{|c|c|c|}
\hline Group & Species & $\begin{array}{l}\text { Trophic } \\
\text { level }^{\mathrm{a}}\end{array}$ \\
\hline Shrimps & $\begin{array}{l}\text { Penaeus brasiliensis } \\
\text { Penaeus spp. } \\
\text { Xiphopenaeus kroyeri }\end{array}$ & $\begin{array}{l}2.3 \\
2.3 \\
2.3\end{array}$ \\
\hline Lobsters & $\begin{array}{l}\text { Panulirus argus } \\
\text { Panulirus spp. }\end{array}$ & $\begin{array}{l}2.6 \\
2.6\end{array}$ \\
\hline $\begin{array}{l}\text { Small and mid-size } \\
\text { pelagics }\end{array}$ & $\begin{array}{l}\text { Sardinella brasiliensis }{ }^{\mathrm{b}} \\
\text { Engraulididae } \\
\text { Scomber japonicus } \\
\text { Scomberomorus spp. }\end{array}$ & $\begin{array}{l}2.8 \\
3.0 \\
3.1 \\
3.3\end{array}$ \\
\hline Common squids & Loligo spp. & 3.4 \\
\hline $\begin{array}{l}\text { Miscellaneous marine } \\
\text { fishes }^{c}\end{array}$ & 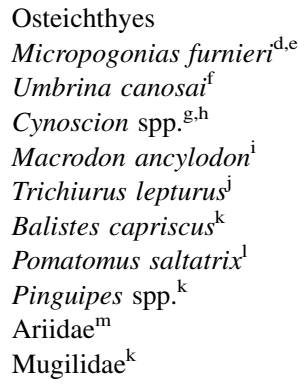 & $\begin{array}{l}3.5 \\
3.4-3.5 \\
3.2 \\
3.9-4.0 \\
4.3 \\
4.3 \\
3.4 \\
4.2 \\
3.8 \\
3.8 \\
3.8\end{array}$ \\
\hline Sharks, rays and skates & Elasmobranchs ${ }^{\mathrm{k}, \mathrm{n}}$ & $3.4-3.8$ \\
\hline Groupers & $\begin{array}{l}\text { Epinephelus spp. } \\
\text { Mycteroperca spp. }\end{array}$ & $\begin{array}{l}3.7 \\
3.7\end{array}$ \\
\hline Snappers & $\begin{array}{l}\text { Lutjanidae } \\
\text { Ocyurus chrysurus }\end{array}$ & $\begin{array}{l}3.8 \\
3.8\end{array}$ \\
\hline Common dolphinfish & Coryphaena hippurus & 3.9 \\
\hline Skipjack tuna & Katsuwonus pelamis $^{\mathrm{O}}$ & 3.9 \\
\hline Tuna-like fishes ${ }^{\mathrm{p}, \mathrm{q}, \mathrm{r}}$ & $\begin{array}{l}\text { Thunnus alalunga } \\
\text { Thunnus albacares } \\
\text { Thunnus atlanticus } \\
\text { Thunnus obesus }\end{array}$ & $\begin{array}{l}3.9 \\
3.9 \\
3.9 \\
3.9\end{array}$ \\
\hline
\end{tabular}

Table 2 (Continued)

\begin{tabular}{|c|c|c|}
\hline Group & Species & $\begin{array}{l}\text { Trophic } \\
\text { level }^{\text {a }}\end{array}$ \\
\hline & Thunnus thynnus & 3.9 \\
\hline & Xiphias gladius & 3.9 \\
\hline & Other Scombroidei & 3.9 \\
\hline
\end{tabular}

${ }^{\mathrm{a}}$ Trophic level estimates are from the model in Fig. 2, from diet composition studies (references in table footnote), and/or from other published trophic models (Christensen and Pauly, 1993).

${ }^{\mathrm{b}}$ Goitein (1983) and Gasalla and Oliveira (1997).

${ }^{c}$ Vazzoler et al. (2000).

${ }^{\mathrm{d}}$ Gasalla (1995).

e Vazzoler (1975).

${ }^{\mathrm{f}}$ Haimovici et al. (1989).

${ }^{g}$ Gasalla (1995).

${ }^{\mathrm{h}}$ Vieira (1990).

${ }^{\mathrm{i}}$ Juras and Yamaguti (1985).

${ }^{\mathrm{j}}$ Martins and Haimovici (1997).

${ }^{\mathrm{k}}$ Froese and Pauly (1998).

${ }^{1}$ Haimovici and Krug (1992).

${ }^{\mathrm{m}}$ Araujo (1984).

${ }^{\mathrm{n}}$ Soares et al. (1992).

${ }^{\circ}$ Vilela (1990).

${ }^{\mathrm{p}}$ Zavala-Camin (1987).

${ }^{q}$ Vaske (1992).

${ }^{\mathrm{r}}$ Vyalov and Ovchinnikov (1980).

quently passed on to the next trophic level or harvested. PPR estimates are based on a conversion factor of $0.06 \mathrm{~g}$ carbon $=1 \mathrm{~g}$ wet weight of catches (Walsh, 1981) and on the mean transfer efficiency per trophic level, i.e.

$\mathrm{PPR}=$ catches $\alpha^{(\mathrm{TL}-1)}$

where $\alpha=\mathrm{TE}^{-1}$, and TE is the mean trophic transfer efficiency between consecutive trophic levels (TLs). PPR is commonly expressed as a percentage of the total primary production $(\% \mathrm{PP})$. 
In order to account for uncertainties on parameter estimates, a Monte Carlo sampling procedure was designed to generate confidence intervals around the estimated PPR values. Two sources of uncertainties were considered: uncertainty on primary production, which was represented by triangular distributions defined by the most likely, minimum and maximum values in Table 1 , and uncertainty on the species trophic level, which we considered to be within a $10 \%$ error around our estimates. Relatively small variations in the trophic level of an organism are expected from shifts in its diet following changes in prey abundance, but large variations will be generally limited by biological constraints imposed, for instance, by morphology (e.g. a piscivore will never succeed in filter-feeding on plankton).

Catch statistics obtained from Haimovici et al. (1997), Haimovici (1998) and from the Instituto de
Pesca, São Paulo, and IBAMA/CEPSUL were used in the analysis of PPR between the two shelf regions. FAO catch statistics of reported Brazilian catches were used to compute the mean trophic level of landings in Brazil from 1950 to 1994.

We explored the ecosystem effects of "fishing down the food web" for anchovy in the southern shelf with a simplified mass-balance model (ECOPATH; Christensen and Pauly, 1992) of the trophic interactions in the pelagic ecosystem (Tables 3 and 4, Fig. 2). The model was constructed based on the pelagic species association described by Mello et al. (1992) for the winter and spring, and depicts anchovy as the dominant planktivorous fish species, being responsible for most of the transfer of energy from lower trophic levels to higher order consumers (Fig. 2). The system is defined by the coordinates $32-43^{\circ} 30^{\prime} \mathrm{S}$ and $51-54^{\circ} \mathrm{W}$ with a total area of $28661 \mathrm{~km}^{2}$.

Table 3

Parameters of the trophic model of the pelagic ecosystem off southern Brazil ${ }^{\mathrm{a}}$

\begin{tabular}{|c|c|c|c|c|c|c|}
\hline Species/group & TL & $B\left(\mathrm{t} \mathrm{km}^{-2}\right)$ & $P / B$ (per year) & $Q / B$ (per year) & $\mathrm{EE}$ & $\begin{array}{l}\text { Yield } \\
\left(\mathrm{t} \mathrm{km}^{-2} \text { per year }\right)\end{array}$ \\
\hline Cutlassfish & 4.25 & $0.240^{\mathrm{b}}$ & $0.410^{\mathrm{d}}$ & $2.050^{\mathrm{e}}$ & 0.852 & $0.015^{\mathrm{c}}$ \\
\hline Hake & 4.11 & 0.085 & $0.355^{\mathrm{d}}$ & $1.750^{\mathrm{e}}$ & 0.950 & $0.004^{\mathrm{c}}$ \\
\hline Sharks & 3.94 & 0.342 & $0.400^{\mathrm{f}}$ & $4.000^{\mathrm{f}}$ & 0.950 & $0.130^{\mathrm{c}}$ \\
\hline Other pelagics & 4.02 & 0.748 & $0.570^{f}$ & $5.300^{f}$ & 0.950 & $0.405^{\mathrm{g}}$ \\
\hline Weakfish & 3.59 & $2.000^{\mathrm{h}}$ & $0.480^{\mathrm{d}}$ & $2.340^{\mathrm{e}}$ & 0.935 & $0.306^{\mathrm{c}}$ \\
\hline Mackerel & 3.11 & 1.329 & $0.340^{\mathrm{f}}$ & $2.710^{\mathrm{e}}$ & 0.950 & $0.033^{\mathrm{g}}$ \\
\hline Jack Mackerel & 3.11 & $0.300^{\mathrm{i}}$ & $0.350^{\mathrm{i}}$ & $3.000^{\mathrm{e}}$ & 0.958 & $0.054^{\mathrm{g}}$ \\
\hline Anchovy & 3.00 & $13.710^{\mathrm{j}}$ & $1.290^{\mathrm{k}}$ & $5.155^{\mathrm{e}}$ & 0.240 & - \\
\hline Squids & 3.32 & $0.200^{1}$ & $1.500^{\mathrm{f}}$ & $3.230^{\mathrm{f}}$ & 0.894 & - \\
\hline Marine shrimps & 2.00 & 0.298 & $3.930^{\mathrm{m}}$ & $19.130^{\mathrm{f}}$ & 0.950 & $0.040^{\mathrm{g}}$ \\
\hline Zooplankton & 2.11 & $9.000^{\mathrm{n}}$ & $64.920^{\mathrm{n}}$ & 324.600 & 0.619 & - \\
\hline Phytoplankton & 1.00 & $16.700^{\circ}$ & $100.000^{\circ}$ & - & 0.965 & - \\
\hline Detritus & 1.00 & $150.000^{\mathrm{p}}$ & - & - & 1.148 & - \\
\hline
\end{tabular}

\footnotetext{
${ }^{\text {a }}$ Values in italic and trophic levels (TLs) were estimated by the model.

${ }^{\mathrm{b}}$ Martins and Haimovici (1997).

${ }^{\mathrm{c}}$ Haimovici (1998).

${ }^{\mathrm{d}}$ Based on Peterson and Wroblewski (1984).

e Based on Palomares and Pauly (1989).

${ }^{\mathrm{f}}$ Based on other trophic models (Christensen and Pauly, 1993).

${ }^{\mathrm{g}}$ Haimovici et al. (1997).

${ }^{\mathrm{h}}$ IBAMA (1993).

${ }^{\mathrm{i}}$ Saccardo (1980).

${ }^{\mathrm{j}}$ Lima and Castello (1995).

${ }^{\mathrm{k}}$ Freire (unpublished).

${ }^{1}$ Haimovici (1997).

${ }^{m}$ D'Incao (1991).

${ }^{\mathrm{n}}$ Resgalla Jr. (unpublished).

${ }^{\circ}$ Odebrecht and Garcia (1997).

p According to Pauly et al. (1993).
} 
Table 4

Diet matrix of the model of the pelagic ecosystem off southern Brazil ${ }^{\mathrm{a}}$

\begin{tabular}{|c|c|c|c|c|c|c|c|c|c|c|c|}
\hline Prey/predator & 1 & 2 & 3 & 4 & 5 & 6 & 7 & 8 & 9 & 10 & 11 \\
\hline 1. Cutlassfish ${ }^{\mathrm{b}}$ & 0.140 & - & - & - & - & - & - & - & - & - & - \\
\hline 2. Hake $\mathrm{c}^{\mathrm{c}}$ & 0.020 & 0.100 & - & - & - & - & - & - & - & - & - \\
\hline 3. Sharks ${ }^{\mathrm{d}}$ & - & - & - & - & - & - & - & - & - & - & - \\
\hline 4. Other pelagics ${ }^{\mathrm{e}}$ & - & - & - & - & - & - & - & - & - & - & - \\
\hline 5. Weakfish ${ }^{\mathrm{e}, \mathrm{f}}$ & 0.120 & - & 0.050 & 0.050 & 0.050 & - & - & - & 0.050 & - & - \\
\hline 6. Mackerel $^{\mathrm{e}}$ & - & - & - & 0.100 & - & - & - & - & - & - & - \\
\hline 7. Jack Mackerel ${ }^{\mathrm{e}}$ & 0.030 & 0.030 & 0.020 & - & - & - & - & - & - & - & - \\
\hline 8. Anchovy ${ }^{\mathrm{g}}$ & 0.570 & 0.800 & 0.330 & 0.300 & 0.450 & - & - & - & 0.150 & - & - \\
\hline 9. Squids ${ }^{\mathrm{h}}$ & 0.050 & 0.030 & 0.030 & 0.050 & - & - & - & - & - & - & - \\
\hline 10. Mar. shrimps ${ }^{\mathrm{i}}$ & 0.010 & - & 0.070 & & 0.200 & 0.010 & - & - & - & - & - \\
\hline 11. Zooplankton & 0.010 & - & - & 0.050 & 0.200 & 0.990 & 1.000 & 0.900 & 0.800 & - & 0.100 \\
\hline 12. Phytoplankton & - & - & - & - & - & - & - & 0.050 & - & 0.200 & 0.550 \\
\hline 13. Detritus & - & - & - & - & - & - & - & 0.050 & - & 0.800 & 0.350 \\
\hline Import & 0.050 & 0.040 & 0.500 & 0.450 & 0.100 & - & - & - & - & - & - \\
\hline
\end{tabular}

${ }^{a}$ Values represent the proportion of the diet of a predator (column) made of a given prey (row). Some of the groups (mainly sharks, weakfish, and other pelagics) have several feeding habitats such as the outer shelf and benthic habitats. For these groups an import was included as a "prey" in the diet composition.

${ }^{\mathrm{b}}$ Martins (1992).

${ }^{\mathrm{c}}$ Haimovici et al. (1993).

${ }^{\mathrm{d}}$ Castello et al. (1997).

${ }^{\text {e }}$ Castello (1997).

${ }^{\mathrm{f}}$ Vieira (1990).

${ }^{\mathrm{g}}$ Schwingel and Castello (1995).

${ }^{\mathrm{h}}$ Haimovici (1997).

${ }^{\mathrm{i}}$ Based on other trophic models (Christensen and Pauly, 1993).

Trophic mass-balance models in ECOPATH rely on a system of linear equations which for any given group $i$ can be represented for any time interval by

$B_{i}\left(\frac{P}{B}\right)_{i} \mathrm{EE}_{i}-\sum_{j=1}^{n} B_{j}\left(\frac{Q}{B}\right)_{j} \mathrm{DC}_{j i}-(Y+\mathrm{EX})_{i}=\Delta B_{i}$

where $B_{i}$ is the biomass of $i$ during the period in question, $(P / B)_{i}$ the production/biomass ratio, $\mathrm{EE}_{i}$ the ecotrophic efficiency, i.e. the fraction of the production of $i$ that is consumed within the system or harvested, $Y_{i}$ the yield (with $Y_{i}=F_{i} B_{i}$, and $F$ as the fishing mortality), $B_{j}$ the biomass of consumers or predators, $(Q / B)_{i}$ the food consumption per unit of biomass of $j$, and $\mathrm{DC}_{j i}$ the fraction of $i$ in the diet of $j$. $\Delta B_{i}$ is the biomass accumulation rate per time in cases where the analysis does not use data from an initial equilibrium situation. "Fishing down the food web" was simulated by increasing fishing mortality $F$ for anchovy from 0 to 1 per year, while maintaining $F$ constant for other exploited groups. We used ECOSIM (Walters et al., 1997) to calculate the predicted changes in equilibrium biomasses of species/group and the total catch from the system over the range of $F$ values for anchovy. The model provides biomass predictions of each group in the system as affected directly by fishing and predation, changes in food availability, and indirectly by fishing or predation on other groups in the system (Walters et al., 1997). Different hypotheses about "top-down" versus "bottom-up" control of trophic interactions were tested by setting the maximum instantaneous mortality rate that consumer $j$ could ever exert on food resource $i$ (see Walters et al., 1997). Setting low values (in our case four times the baseline mortality rate) lead to bottomup control where prey availability governs the productivity of predators, while high values (20 times the baseline mortality rate) lead to top-down control where changes in the biomass of predators lead to cascade effects in the food web. 


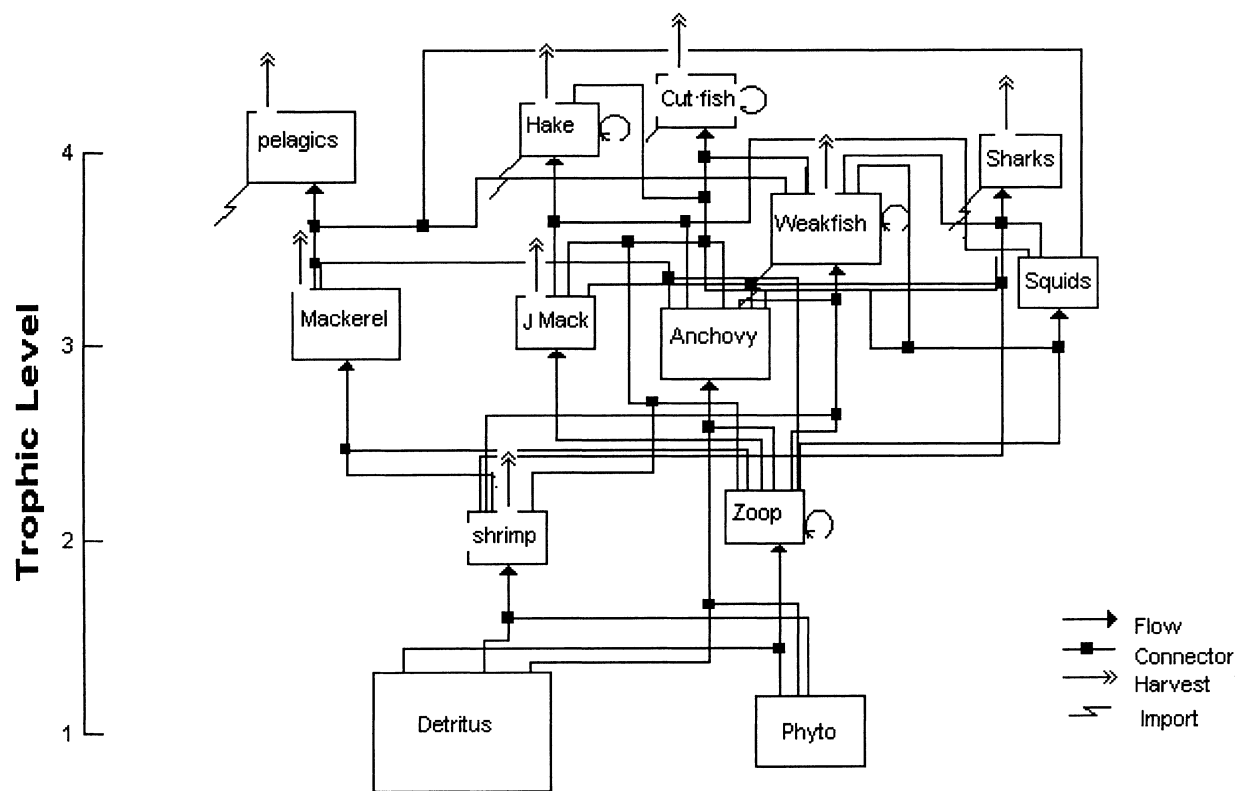

Fig. 2. Flowchart of trophic relationships in the pelagic association off southern Brazil. It describes the flows between groups (boxes), the biomass of each group (area of boxes proportional to the log of biomass), and the respective trophic levels. Only the consumption flows are shown. For full parameter descriptions, see Tables 3 and 4.

\section{Results}

\subsection{PPR and trophic levels}

PPR estimates by shelf region and species landed are shown in Tables 5-7. Fig. 3 shows the expected
PPR when uncertainties on primary production and species trophic level are taken into account. Fisheries in southern Brazil already use a large proportion of the productive capacity of the shelf ecosystems. In the south, primary production required to sustain catches has changed little from the 1970s to the 1990s, being

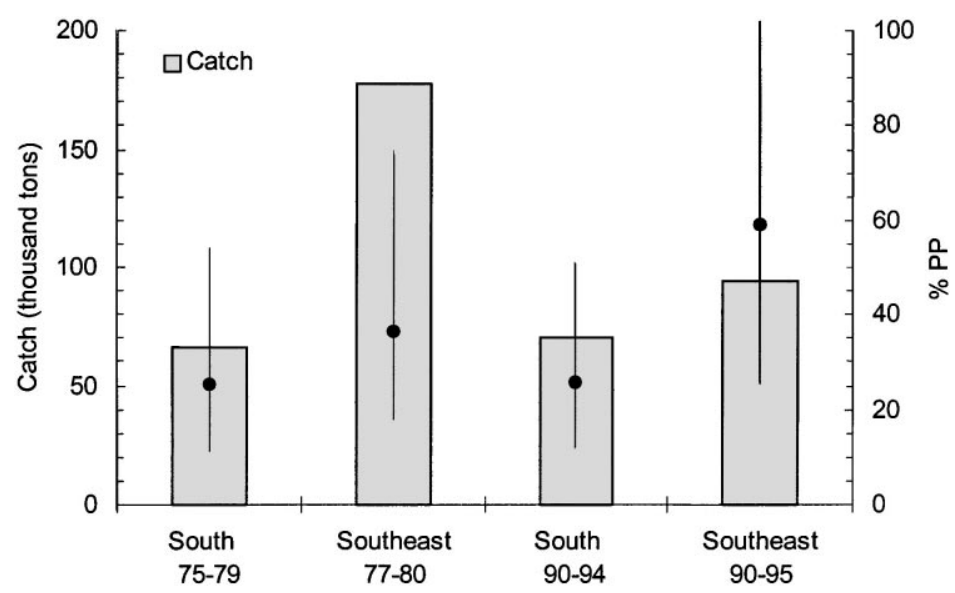

Fig. 3. Fisheries landings and PPR estimates for the south and southeast during two time periods. PPR is expressed as percentage of total primary production. The mean (dot) and $95 \%$ interval (line) of PPR estimates were obtained by resampling from the primary production and trophic level estimates. 
Table 5

Trophic level, mean catch and PPR estimates for the southern shelf

\begin{tabular}{|c|c|c|c|c|c|}
\hline \multirow[t]{2}{*}{ Species } & \multicolumn{3}{|c|}{ 1975-1979 } & \multicolumn{2}{|l|}{ 1990-1994 } \\
\hline & $\begin{array}{l}\text { Trophic } \\
\text { level }\end{array}$ & Catches $(\mathrm{t})$ & $\begin{array}{l}\text { PPR } \\
\left(\times 10^{10} \mathrm{gC}\right)\end{array}$ & Catches $(\mathrm{t})$ & $\begin{array}{l}\text { PPR } \\
\left(\times 10^{10} \mathrm{gC}\right)\end{array}$ \\
\hline Micropogonias furnieri & 3.5 & 14308 & 42.8 & 14709 & 44.1 \\
\hline Umbrina canosai & 3.2 & 16900 & 26.2 & 9629 & 14.9 \\
\hline Cynoscion guatacupa & 3.9 & 6439 & 66.5 & 8785 & 90.7 \\
\hline Macrodon ancylodon & 4.3 & 7941 & 184.0 & 3966 & 91.9 \\
\hline Miscellaneous teleosteans ${ }^{\mathrm{a}}$ & 3.5 & 4052 & 16.2 & 4143 & 14.2 \\
\hline Netuma spp. & 3.8 & 3983 & 31.1 & 615 & 4.8 \\
\hline Trichiurus lepturus & 4.3 & 75 & 1.8 & 441 & 11.0 \\
\hline Demersal sharks ${ }^{\mathrm{b}}$ & 3.8 & 2584 & 17.4 & 5931 & 39.8 \\
\hline Rhinobatus horkelli & 3.4 & 1010 & 2.95 & 460 & 1.3 \\
\hline Rays and skates & 3.6 & 116 & 0.5 & 746 & 3.2 \\
\hline Marine shrimps & 2.3 & - & - & 1148 & 0.2 \\
\hline Small and mid-size pelagics ${ }^{c}$ & 3.2 & 1549 & 1.4 & 3848 & 5.2 \\
\hline Pomatomus saltatrix & 4.2 & 4290 & 89.8 & 3521 & 73.7 \\
\hline Mugil spp. & 3.8 & 2081 & 14.7 & 1524 & 10.8 \\
\hline Katsuwonus pelamis & 3.9 & - & - & 8088 & 71.8 \\
\hline Pelagic sharks & 3.7 & 182 & 1.0 & 547 & 3.0 \\
\hline Tuna-like fishes & 3.9 & 915 & 8.5 & 2402 & 22.4 \\
\hline
\end{tabular}

${ }^{a}$ Pogonias cromis; Merluccius hubbsi; Paralichthys spp., Pagrus pagrus; Prionotus punctatus; Urophycis brasiliensis and Poliprion americanus.

${ }^{\mathrm{b}}$ Mostly Galeorhinus galeus; Mustelus schmitti and Squatina spp.

${ }^{\mathrm{c}}$ Brevoortia pectinata; Scomber japonicus and Trachurus lathami.

in the order of $27 \%$ of the total primary production. Little change is also observed in the mean trophic level of fisheries in the south which have been targeting mostly high-trophic level species (Tables 5 and 7). An increase in catches of tunas and sharks was observed in the southern shelf in the early 1990s accompanying the depletion of important demersal fish stocks, such as Umbrina canosai, Macrodon ancylodon and catfish species, Netuma spp. (Table 5). This alternation of species in the catches did not result in major changes in the PPR or in the mean trophic level of landings between the two periods.

Landings in the southeast are on the other hand dominated by low-trophic level species, sardine and marine shrimps being the most important stocks in terms of catch volume (Table 6). With the collapse of

Table 6

Trophic level, mean catch and PPR estimates for the south-eastern shelf

\begin{tabular}{|c|c|c|c|c|c|}
\hline \multirow[t]{2}{*}{ Species } & \multirow[t]{2}{*}{ Trophic level } & \multicolumn{2}{|l|}{$1977-1980$} & \multicolumn{2}{|l|}{ 1990-1995 } \\
\hline & & Catches $(t)$ & PPR $\left(\times 10^{10} \mathrm{gC}\right)$ & PPR $\left(\times 10^{10} \mathrm{gC}\right)$ & \\
\hline Micropogonias furnieri & 3.4 & 7126 & 63.9 & 4541 & 40.7 \\
\hline Macrodon ancylodon & 3.7 & 2053 & 36.7 & 1870 & 33.4 \\
\hline Cynoscion jamaiscencis & 4.0 & 1921 & 92.2 & 2245 & 107.7 \\
\hline Balistes capriscus & 3.4 & - & - & 2144 & 19.8 \\
\hline Sardinella brasiliensis & 2.8 & 146520 & 193.2 & 54414 & 71.7 \\
\hline Rays and skates & 3.4 & & & 504 & 4.7 \\
\hline Marine shrimps & 2.3 & 17371 & 5.1 & 13997 & 4.1 \\
\hline Sharks & 3.8 & 517 & 12.8 & 2144 & 53.2 \\
\hline Katswonus pelamis & 3.9 & 1380 & 47.6 & 7197 & 248.5 \\
\hline Tuna-like fishes & 3.9 & 694 & 25.4 & 4771 & 174.9 \\
\hline
\end{tabular}


Table 7

Summary statistics of the mean catch, mean trophic level (TL), mean transfer efficiency (TE), the primary production required by fisheries catches (PPR), and the percentage of the total primary production appropriated by fisheries (\%PP) in the southern and south-eastern shelves

\begin{tabular}{|c|c|c|c|c|c|}
\hline Region & Catch (t per year) & $\mathrm{TL}$ & $\mathrm{TE}(\%)^{\mathrm{a}}$ & $\begin{array}{l}\text { PPR } \\
\left(\times 10^{10} \mathrm{gC} \text { per year }\right)\end{array}$ & $\% \mathrm{PP}$ \\
\hline \multicolumn{6}{|l|}{ Southern } \\
\hline 1975-1979 & 66425 & 3.6 & 8 & 505 & 27.7 \\
\hline 1990-1994 & 70503 & 3.6 & & 503 & 27.6 \\
\hline \multicolumn{6}{|l|}{ South-eastern } \\
\hline 1977-1980 & 177582 & 2.8 & 5 & 477 & 33.1 \\
\hline 1990-1995 & 93826 & 3.1 & & 758 & 52.7 \\
\hline
\end{tabular}

${ }^{a}$ Transfer efficiencies are estimated from trophic models in Rocha et al. (1998) and from this paper.

the Brazilian sardine during the late 1980s and early 1990s, and the increase in tuna and sharks catches, there was an increase in the mean trophic level of fisheries from 2.8 to 3.1 (Table 7). Although catches were considerably lower in the latter period, the change in relative importance of the species landed resulted in an increase in PPR from 33.1 to $52.7 \%$ of the total shelf primary production. Note that PPR values as high as $100 \%$ are obtained for the southeastern shelf depending on the input values for primary production and trophic level (Fig. 3). Higher PPR values in the southeast result from the combined effect of higher catches, lower primary productivity and lower trophic transfer efficiencies compared to the southern shelf (Table 7).

The increasing trend in the mean trophic level of catches is also observed in the FAO fisheries statistics for Brazil (Fig. 4). Fisheries in Brazil had a relatively constant mean trophic level of the species landed from 1950 to the early 1980s, but show a recent increase in mean trophic level caused by the combined effect of the collapse of small and mid-size pelagics (mostly sardine) and the increasing landings of large pelagic fishes (tunas and sharks) with the development of offshore fisheries.

\subsection{Fishing down the food web}

A strategy very often proposed to increase catches in exploited ecosystem is to fish down the food web for highly abundant, small pelagic planktivorous fishes, after larger species are depleted. Simulation results of fishing down food web scenario for anchovy in the southern shelf are shown in Figs. 5 and 6. Fig. 5 represents the predicted equilibrium yield and biomass of anchovy, and the percentage change in biomass of all other groups in the system under "topdown" and "bottom-up" control of trophic interactions. The model predicts considerably smaller yields and optimal fishing mortality rates for anchovy under top-down control $\left(F_{\text {msy }}\right.$ top-down $\sim 0.1$ per year; $F_{\text {msy }}$ bottom-up $\sim 0.3$ per year). Both hypotheses generate a similar pattern of decrease in biomass of higher trophic level species, increase in biomass of midtrophic level groups and increase in zooplankton biomass with increasing $F$ for anchovy. Predictions of biomass changes at the mid-trophic level are more pronounced under top-down control, where the release in predation mortality due to the depressed biomass of top predators leads to a sharp increase of jack mackerel abundance.

Fig. 6a shows the changes in the total production (catches from all groups) at trophic level with increasing equilibrium fishing mortality for anchovy. Fishing down the food web has the effect of increasing yield up to a threshold fishing mortality rate for anchovy $F_{\text {msy }}$ beyond which fisheries production become gradually impaired by overfishing and by divergence or complete interruption of major energy pathways to the higher trophic levels. With the overfishing of anchovy, total catches decrease and the mean trophic level of catches increases (lesser low-trophic level species in the catches). The backward bending curve between the mean trophic level of catches and total catch suggests that production at trophic level becomes considerably smaller when anchovy is overfished, i.e. the system is unable to capitalize the energy previously available for fisheries and other organisms at the higher trophic 

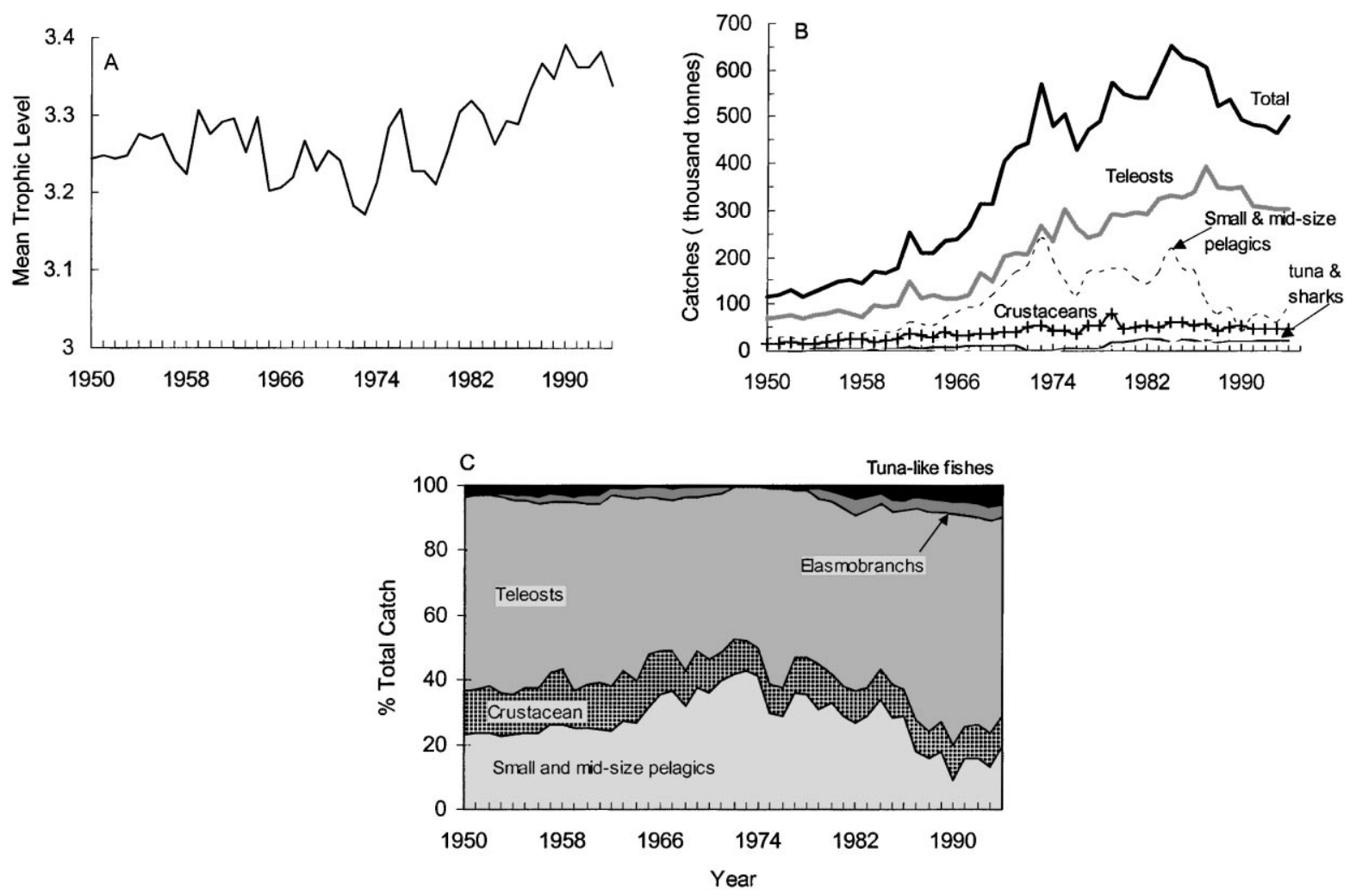

Fig. 4. Mean trophic level (A), and species composition (B and C) of total Brazilian landings (source: FAO).

levels. The depressed abundance and productivity of top predators in turn impede the complete recovery of the mean trophic level of catches, which become composed mainly by mid-trophic level groups also targeted by fisheries. Parallel changes occur in the mean trophic level of the system (Fig. 6b). The mean trophic level of the system is smaller than that of fisheries catches (due to the contribution of zooplankton and phytoplankton), and shows a progressive decrease with the increase in anchovy exploitation. With "bottom-up" control, total system production at the end of the simulation is smaller than that originally obtained before fishing down the food web. These generic effects are attenuated under "top-down" control when the model predicts that total catch may remain high after anchovy depletion as a result of the sharp increase in abundance of other mid-trophic level species (e.g. Jack Mackerel, Fig. 5) also targeted by fisheries.

\section{Discussion}

The primary production required to sustain marine capture fisheries in southern Brazil is estimated to vary between 27 and $53 \%$ of the total shelf primary production. Results indicate a level of fisheries impact in this portion of the Brazilian coast comparable to the most intensively exploited temperate shelf ecosystems of the world (Pauly and Christensen, 1995), where fisheries utilize up to one-third of the primary production. Fisheries in the upwelling ecosystem of the south-eastern shelf appropriate a larger proportion of the primary production than in the southern shelf due to the combined effect of higher catches, lower primary productivity and lower trophic transfer efficiencies. Upwelling ecosystems are considered relatively inefficient in transferring energy up the food web. Trophic transfer efficiencies of ca. 5\% were estimated by Jarre-Teichman and Christensen 

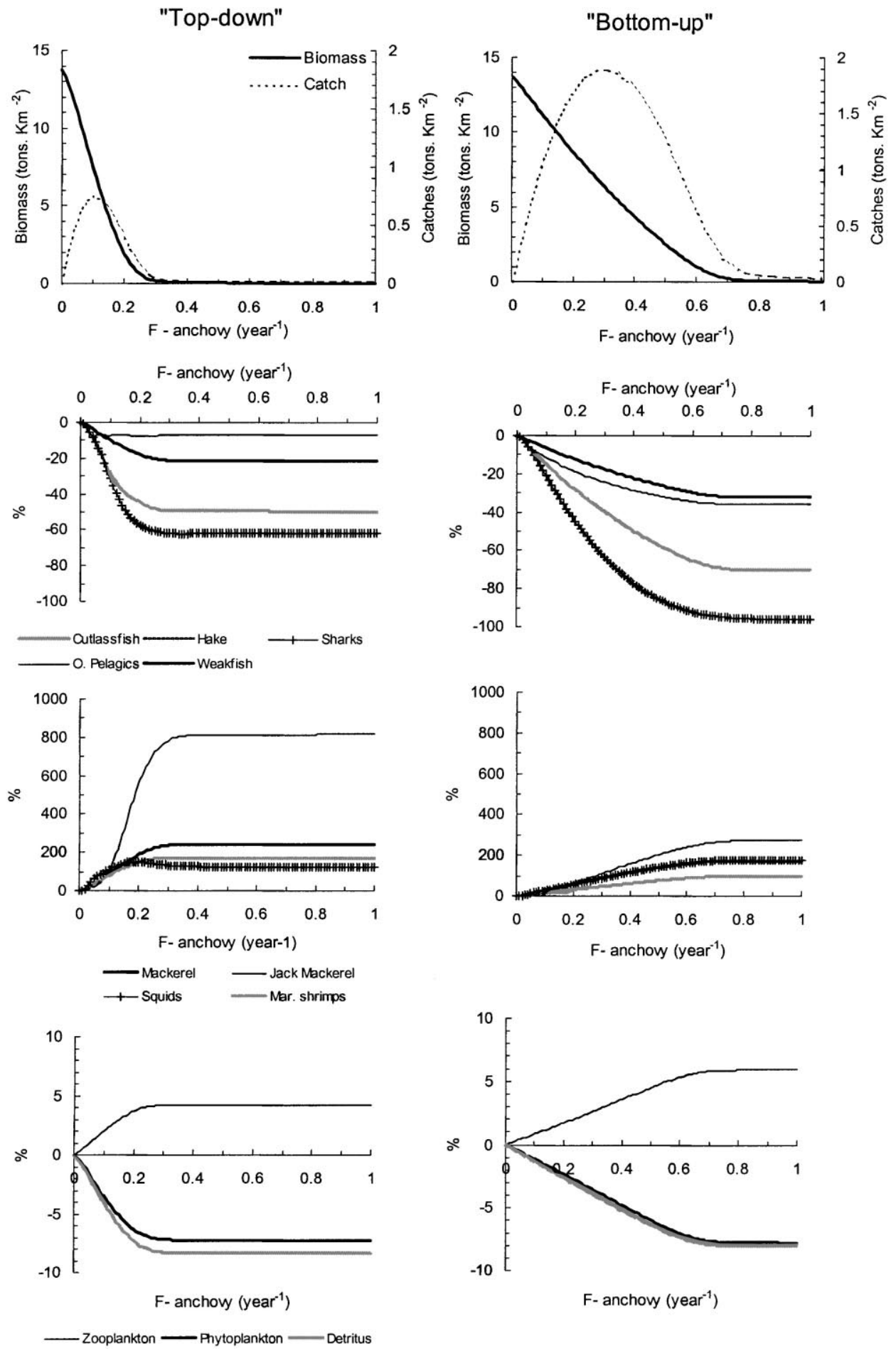

Fig. 5. Equilibrium simulation of increasing fishing mortality for anchovy. Upper panel represents the predicted equilibrium yield and absolute biomass of anchovy. Lower panels show the predicted relative change in biomass of all other groups in the system. 

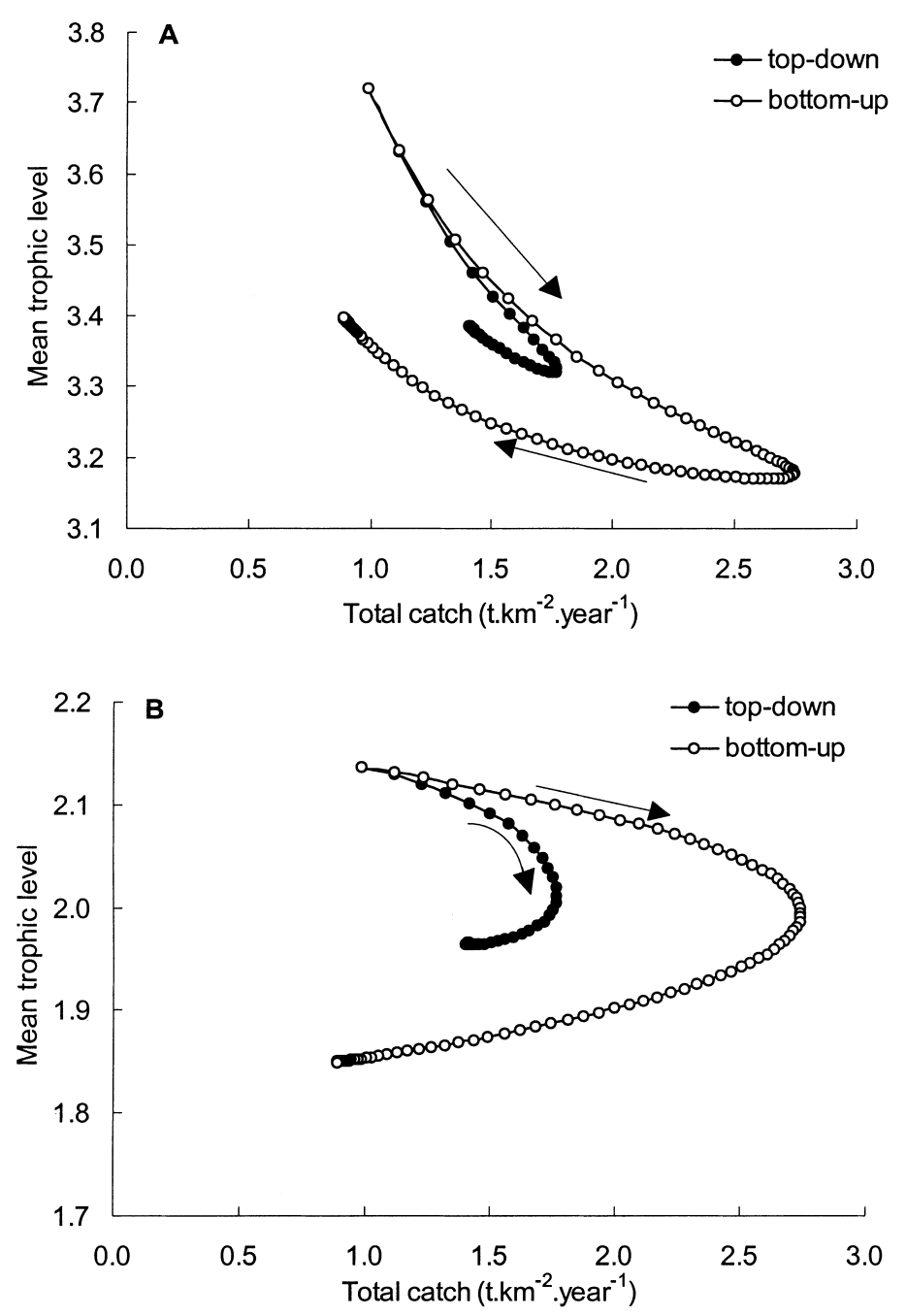

Fig. 6. Relationship between (A) total catch from the system and the mean trophic level of catches, and (B) total catch and the mean trophic level of the system (detritus excluded) with increasing fishing mortality for anchovy. The arrows indicate the direction of increase in $F$, and the dots correspond to 0.01 increments in fishing mortality (from 0 to 1 per year).

(1998) for four major upwelling ecosystems, which are lower than the mean of ca. $10 \%$ computed across different types of aquatic ecosystems (Pauly and Christensen, 1995). Their energetic inefficiency seems to be related to the characteristics of primary productivity and food web organization. The high and variable new primary production characteristic of upwelling systems yields a higher export of carbon compared to more stable and less productive systems, where most of the primary production is regenerated (Berger et al., 1989).
Our PPR estimates may be conservative considering that discards were not included in the calculations, and that part of the catches may remain unreported in official fisheries statistics (Gasalla and Tomás, 1998). Both unreported catches and discards can cause the underestimation of the footprint of fisheries, and bias the estimated mean trophic level of landings. Haimovici et al. (1997) suggested that discards might represent ca. $25 \%$ of total annual catches in the southern shelf. Including discards in our estimates for this region, with the same mean trophic level of the species 
landed, raises the expected PPR for the early 1990s from $503 \times 10^{10}$ to $611 \times 10^{10} \mathrm{gC}$ per year and from 27.6 to $33.5 \%$ of the total primary production. The high PPR values in the southern shelf corroborate the fact that most commercially important estuarine, coastal, and shelf stocks are either fully or overexploited in the region, and landings are expect to decrease with current fishing pressure (Haimovici et al., 1997). The prospect of increasing catches in the region has to come from two non-exclusive strategies: (i) by better utilizing or recovering stocks which are currently overfished, such as most demersal stocks (Table 5), and/or (ii) by "fishing down the food web" for alternative resources not yet utilized, mostly anchovy and jack mackerel (Haimovici et al., 1997).

Fishing down the food web has been shown to increase catches up to threshold fishing intensity beyond which fisheries production may become impaired by shifts in major energy pathways in the system (Fig. 6). Can this type of fisheries-induced change in the ecosystem happen? Fishing down the food web is not an observed phenomenon in Brazil. Instead, fisheries have been targeting high-trophic level species, with the exception of sardine in the southeast, and show a recent increasing trend due to the development of offshore fisheries for high-trophic level species such as tunas and pelagic sharks. This increasing trend of mean trophic level of fish landings was also obtained by Pauly et al. (1998) for the Southwest Atlantic, and attributed to the development of new fisheries, which, according to the authors, tend to mask the fishing down the food web phenomenon. In Brazil, both national and regional data indicate that although fisheries expanded into areas/stocks not previously exploited there is no underlying downward trend in the mean trophic level of catches.

Regional experience with intensive fishing for a forage species in south-eastern Brazil has shifted a system that once supported a large fishery for sardine to one occupied by an abundant population of anchovy, Engraulis anchoita, that is not commercially harvested (Castello et al., 1991). Nonetheless, the extent to which the collapse of the sardine fishery and the switch to an anchovy-dominated system was due to human or natural factors is still inconclusive (Rossi-Wongtschowski et al., 1996). Many marine ecosystems underwent major "regime shifts" or changes in species composition and production rates apparently triggered by environmental factors but intensified by the effect of fisheries (Steele, 1996). Among the most documented examples are the sardine/anchovy switches in coastal upwelling systems (Lluch-Belda et al., 1989), the gadoid outbursts in the North Sea (Cushing, 1980; Daan, 1980), and the decline of marine mammals and outburst of pollock in the Bering Sea (Trites et al., 1999). On the other hand, recent global assessments of the trophic level of marine fisheries (Pauly et al., 1998) provide evidence of the fishing down food web phenomenon and of associated fisheries-induced changes in the food webs similar to that predicted in Fig. 6.

Much scientific debate on the causes of shifts in species compositions in many marine ecosystems has been focusing on a "bottom-up" perspective in which the effect of physical forcing, mediated through climatic-oceanographic processes, leads to changes in primary production and reproductive success of fish populations which in turn will trigger changes up in the food web (Beamish, 1995; Bakun, 1996). An alternative "top-down" perspective, mostly applied in the study of lakes, asserts that predation affects directly and indirectly the structure of populations and communities, and production processes at all trophic levels in the food web (Kitchell et al., 1994). Model simulations allowed us to explore the effects of both assumptions in predicting the changes in the food web accompanying the exploitation of anchovy. Under topdown control, the system responded with a marked increase in the biomass of a competitor species due to cascade effects in the food web. This pattern was not observed under bottom-up control, when competitions for food resources were limiting interactions. These results, also obtained by Mackinson et al. (1997) for other ecosystems, differ from the early emphasis placed on food competition as the driving force of species replacement (Cushing, 1980; Daan, 1980), but reinforce the potential role of predation mechanisms and trophic cascades effects in shaping the dynamics of mid-trophic level, forage species. The predicted $F_{\text {msy }}$ values for anchovy were also very sensitive to the type of control of trophic interactions. Bottom-up control generally produces a catch curve that achieves an asymptote at higher $F_{\mathrm{s}}$, predicting that the stock can sustain much higher fishing pressure before it begins to decline. This occurs because under bottom-up control, predation mortality rate $\left(M_{i j}=Q_{i j} / B_{i}\right)$ tends 
to remain more stable, while the consumption rate $\left(Q_{i}\right)$ $B_{i}$ ) of anchovy increases more, due to donor control of total food eaten, making it more productive per biomass. Strong predation control prevents higher yields under top-down control. These results, so far impossible to predict with single-species approaches, offer warning to novice users of multi-species approaches regarding model sensitivity to trophic control assumptions (Mackinson et al., 1997; Walters et al., 1997). The model offers the possibility to test other complementary hypothesis to the classic top-down and bottom-up controls, such as the "wasp waist" control suggested by Rice (1995) to represent ecosystems regulated up and down from the middle usually occupied by small pelagic fish. For the hypotheses tested in this paper, the model predicted optimal fishing mortality rates for anchovy close to the range of sustainable $F_{\mathrm{s}}$ for small pelagic stocks observed by Patterson (1992).

This paper confirms that fisheries in southern Brazil already utilize a large proportion of the marine shelf ecosystem carrying capacity. In line with recent stock assessment reports, this indicates that the prospect of increasing catches and recovering the status of fisheries activities must rely on better management of the stocks currently overfished, and those offshore resources currently moderately exploited (as reported in IBAMA, 1994b; Matsuura, 1995), and/or fishing down the food web for abundant short-lived, planktivorous fishes. It is showed, however, that in an intensively exploited ecosystem the proposal for increasing fisheries production by harvesting at lower levels in the food web has the potential risk of aggravating the depletion of high-trophic level species besides altering the structure of the ecosystem, and thus must be approached with caution. The adoption of precautionary measures and ecosystem principles in fisheries policy decisions has been, at least theoretically, common in fisheries literature and government agendas worldwide (see FAO Code of Conduct for Responsible Fisheries, Oceans Act Canada; GESPE, 1997). One such principle states that "regulation of the use of living resources must be based on understanding the structure and dynamics of the ecosystem of which the resource is a part and must take into account the ecological (...) influences that directly and indirectly affect resource use" (Mangel et al., 1996). If ecosystem principles and precautionary measures are to be effectively implemented, managers and decision makers have to take the possibility of such ecosystem impacts of fishing down the food web into account when designing policies for the exploitation of marine resources.

\section{Acknowledgements}

We thank Daniel Pauly, Jorge Pablo Castello and Manuel Haimovici for valuable suggestions and review of early manuscripts. We also thank Humber A. Andrade, Acácio R.G. Tomás and Flávia M. Saldanha Correia, for providing important data for this work, and Charrid Resgalla Jr., for his participation in the construction of an early version of the trophic model. Thanks are also given to the Instituto de Pesca (São Paulo, Brazil) for supporting a visit of M.A. Gasalla to the FC, UBC. This study was conducted while the author held a sponsorship from the Conselho Nacional de Desenvolvimento Científico e Tecnológico, $\mathrm{CNPq} / \mathrm{Brazil}$.

\section{References}

Alverson, D.L., Freeberg, M.H., Murawski, S.A., Pope, J.G., 1994. A global assessment of fisheries bycatch and discards. FAO Fish. Technical Paper 339, 233.

Araujo, F.J., 1984. Hábitos alimentares de três espécies de bagres marinhos (Ariidae) no estuário da Lagoa dos Patos, RS, Brasil. Atlântica (Rio Grande) 7, 47-63.

Bakun, A., 1996. Patterns in the ocean. Ocean processes and marine population dynamics. California Sea Grant, 323 pp.

Bakun, A., Parrish, R., 1990. Comparative studies of coastal pelagic fish reproductive habitat: the Brazilian sardine (Sardinella aurita). J. Cons. Int. Explor. Mer. 46, 269-283.

Beamish, R.J. (Ed.), 1995. Climate Change and Northern Fish Populations (Canadian Special Publication). Fisheries and Aquatic Sciences 121, 739 pp.

Berger, W.H., Smetacek, V.S., Wefer, G., 1989. Ocean productivity and paleoproductivity - an overview. In: Berger, W.H., Smetacek, V.S., Wefer, G. (Eds.), Productivity of the Ocean: Present and Past. Wiley, New York, pp. 1-35.

Brandini, F.P., 1990. Primary production and phytoplankton photosynthetic characteristics in the south-eastern Brazilian coast. Bolm Inst. Oceanogr. S. Paulo 38 (2), 147-159.

Castello, J.P., 1997. Pelagic teleosts. In: Seeliger, U., Odebrecht, C., Castello, J.P. (Eds.), Subtropical Convergence Environments. The Coast and Sea in the Southwestern Atlantic. Springer, Berlin, pp. 123-128.

Castello, J.P., Habiaga, R.P., Amaral, J.C., Lima Jr., I.D., 1991. Prospecção hidroacústica e avaliação da biomassa de sardinha e 
anchoita na região sudeste do Brasil (outubro/novembro de 1988). Bolm Inst. Oceanogr. S. Paulo 8, 15-30.

Castello, J.P., Haimovici, M., Odebrecht, C., Vooren, C.M., 1997. The continental shelf and slope. In: Seeliger, U., Odebrecht, C., Castello, J.P. (Eds.), Subtropical Convergence Environments. The Coast and Sea in the Southwestern Atlantic. Springer, Berlin, pp. 171-179.

Cergole, M.C., 1995. Stock assessment of the Brazilian sardine, Sardinella brasiliensis, of the south-eastern coast of Brazil. Sci. Mar. 59 (3-4), 597-610.

Christensen, V., Pauly, D., 1992. ECOPATH II - a software for balancing steady-state models and calculating network characteristics. Ecol. Model. 61, 169-185.

Christensen, V., Pauly, D. (Eds.), 1993. Trophic models of aquatic ecosystems. In: ICLARM Conference Proceedings No. 26. ICLARM, Manila, Philippines, 390 pp.

Christensen, V., Pauly, D., 1998. Changes in models of aquatic ecosystems approaching carrying capacity. Ecol. Appl. 8 (1), 104-109.

Cushing, D.H., 1980. The decline of the herring stocks and the gadoid outburst. J. Cons. Int. Explor. Mer. 39, 70-81.

Daan, N., 1980. A review of replacement of depleted stocks by other species and the mechanisms underlying such replacement. Rapp. P. -v. Réun. Cons. Int. Explor. Mer. 177, 405421.

Dias Neto, J., 1991a. A pesca da Piramutaba (Brachyplatystoma vaillanti, Val.) na região norte do Brasil. Atlântica 13 (1), 1120.

Dias Neto, J., 1991b. Pesca de camarões no norte do Brasil. Atlântica 13 (1), 21-28.

Diegues, A.C.S., 1995. Povos e Mares: Leituras em Sócioantropologia Marítma. NUPAUB, University of São Paulo, Brazil, 260 pp.

D’Incao, F., 1991. Pesca e biologia de Penaeus paulensis na Lagoa dos Patos, RS. Atlântica (Rio Grande) 13 (1), 159-169.

Froese, R., Pauly, D. (Eds.), 1998. FishBase '98. Concepts, Design and Data Sources. ICLARM, Manila, Philippines.

Garcia, S.M., Newton, C., 1997. Current situation, trends, and prospects in world capture fisheries. In: Pikitch, E.K., Huppert, D.D., Sissenwine, M.P. (Eds.), Global Trends: Fisheries Management, Vol. 20. Proceedings of the American Fisheries Society Symposium, Maryland, pp. 3-27.

Gasalla, M.A., 1995. Organização trófica da ictiofauna do Saco de Mamanguá, Parati, Estado do Rio de Janeiro. M.Sc Thesis. Instituto Oceanográfico, University of São Paulo, Brazil, 145 pp.

Gasalla, M.A., Oliveira, M.R., 1997. Papel trófico de clupeídeos da costa sudeste do Brasil. In: Proceedings of the XIIth Encontro Brasileiro de Ictiologia (Abstracts). Instituto Oceanográfico, University of São Paulo, São Paulo.

Gasalla, M.A., Tomás, A.R.G., 1998. An evaluation of the status of fisheries data collection and stock assessment problems in São Paulo, south-eastern Brazil. In: Quinn II, T.J., Funk, F., Heifetz, J., Ianelli, J.N., Powers, J.E., Schweigert, J.F., Sullivan, P.J., Zhang, C.-I. (Eds.), Fishery Stock Assessment Models. Alaska Sea Grant College Program, AK-SG-98-01. University of Alaska, Fairbanks.
Goitein, R., 1983. Sardinella brasiliensis (Steindachner, 1879): estudos sobre alimentação nas regiões de Ubatuba $\left(23^{\circ} 26^{\prime} \mathrm{S}\right)$, Santos $\left(24^{\circ} 00^{\prime} \mathrm{S}\right)$ e Cananéia $\left(25^{\circ} 01^{\prime} \mathrm{S}\right)$. Naturalia $8,197-$ 209.

Grupo Executivo do Setor Pesqueiro (GESPE), 1997. Plano básico para o ordenamento da pesca marítma nacional. Relatório do Subgrupo de Trabalho Para a Pesca Marítima, Brazil, Junho de 1997.

Haimovici, M., 1997. Cephalopods. In: Seeliger, U., Odebrecht, C., Castello, J.P. (Eds.), Subtropical Convergence Environments. The Coast and Sea in the Southwestern Atlantic. Springer, Berlin, pp. 146-150.

Haimovici, M., 1998. Present state and perspectives for the southern Brazil shelf demersal fisheries. Fish. Mgmt. Ecol. 5, 277-289.

Haimovici, M., Krug, L.C., 1992. Alimentação e reprodução da enchova Pomatomus saltatrix no litoral sul do Brasil. Rev. Brasil. Biol. (Rio de Janeiro) 52 (3), 503-513.

Haimovici, M., Arruda, M.C., Teixeira, R.L., 1989. Alimentação da castanha Umbrina canosai no litoral sul de Brasil. Rev. Brasil. Biol. (Rio de Janeiro) 49 (2), 511-522.

Haimovici, M., Martins, A.S., Teixeira, R.L., 1993. Distribuición, alimentacíon y observaciones sobre la reproduccíon de la merluza Merluccius hubbsi en el sur de Brasil. Frente Maritmo (Montevideo) 14, 81-86.

Haimovici, M., Castello, J.P., Vooren, C.M., 1997. Fisheries. In: Seeliger, U., Odebrecht, C., Castello, J.P. (Eds.), Subtropical Convergence Environments. The Coast and Sea in the Southwestern Atlantic. Springer, Berlin, pp. 183-196.

Hempel, G., 1971. Southwest Atlantic. In: Gulland, J.A. (Ed.), Fish Resources of the Oceans. Fishing News Books, Oxford, pp. 146-152.

IBAMA, 1993. Peixes demersais. Coleção Meio Ambiente. Séries Estudos Pesca, Brasília, Vol. 8. Ministério do Meio Ambiente, $94 \mathrm{pp}$.

IBAMA, 1994a. Lagosta, Carangueijo-uca e camarão do Nordeste. Relatório das Reuniões dos Grupos Permanentes de Estudos-GPE's, Brasilia, Vol. 10. IBAMA Estudos de Pesca, 190 pp.

IBAMA, 1994b. Sardinha, atuns e afins. Relatorio das Reuniões dos Grupos Permanentes de Estudos-GPE's, Brasilia, Vol. 11. IBAMA Estudos de Pesca, 201 pp.

IBAMA, 1994c. Relatório da reunião do Grupo Permanente de Estudos sobre camarões das regiões sudeste e sul do Brasil. CEPSUL-IBAMA, 4 a 8 de outubro. Itajaí, SC, 1993, 7 pp.

IBAMA/IBGE, 1995. Estatística da Pesca. CEPENE, Tamandaré, PE.

Jarre-Teichman, A., Christensen, V., 1998. Comparative modelling of trophic flows in four large upwelling ecosystems: global versus local effects. In: Durand, M.H., Cury, P., Mendelssohn, R., Roy, C., Bakun, A., Pauly, D. (Eds.), Global Versus Local Changes in Upwelling Systems. ORSTOM Editions, Paris, pp. 425-443.

Juras, A.A., Yamaguti, N., 1985. Food and feeding habits of the king weakfish (Macrodon ancylodon) (Bloch and Schneider 1801) caught in the southern coast of Brasil (Lat 29-32 S). Bolm Inst. Oceanogr. S. Paulo 33 (2), 149-157. 
Kitchell, J.F., Eby, L.A., He, X., Schindler, D.E., Wright, R.A., 1994. Predator-prey dynamics in an ecosystem context. J. Fish Biol. 45 (Suppl. A), 209-226.

Lima, I.D., Castello, J.P., 1995. Distribution and abundance of South-west Atlantic anchovy spawners (Engraulis anchoita) in relation to oceanographic processes in the southern Brazilian shelf. Fish. Oceanogr. 4 (1), 1-16.

Lluch-Belda, D., Crawford, R.J., Kawasaki, T., MacCall, A.D., Parrish, R.H., Schwartzlose, R.A., Smith, P.E., 1989. Worldwide fluctuations of sardine and anchovy stocks: the regime problem. S. Afr. J. Mar. Sci. 8, 195-205.

Mackinson, S., Vasconcellos, M., Sloman, K., Pitcher, T., Walters, C., 1997. Ecosystem impacts of harvesting small pelagic fish in upwelling systems: using a dynamic mass-balance model. In: Proceedings of the Forage Fishes in Marine Ecosystems. Alaska Sea Grabt College Program, pp. 731-749.

Mangel, M., et al., 1996. Principles for the conservation of wild living resources. Ecol. Appl. 6 (2), 262-338.

Martins, A.S., 1992. Bioecologia do peixe-espada, Trichiurus lepturus Linnaeus, 1758, no sul do Brasil. M.Sc. Thesis. University of Rio Grande, Brasil.

Martins, A.S., Haimovici, M., 1997. Distribution, abundance and biological interactions of the cutlassfish Trichiurus lepturus in the southern Brazil subtropical convergence ecosystem. Fish. Res. 30, 217-227.

Matsuura, Y., 1995. Os ecossistemas brasileiros e os principais macrovetores de desenvolvimento. Subsídio ao Planejamento da Gestão Ambiental. Projeto Cenários para o Planejamento da Gestão Ambiental (MMA/PNMA), Brasília, DF, pp. 39-104.

Mello, R.M., Castello, J.P., Freire, K.F.M., 1992. Associacíon de especies pelágicas marinas en el sur de Brasil durante invierno y primavera. Frente Maritmo (Montevideo) 11, 63-69.

Neiva, G.S., Moura, S.J.C., 1977. Sumário sobre a exploração de recursos marinhos do litoral brasileiro: situação atual e perspectivas. PDP-SUDEPE, Vol. 27. Série Doc. Ocasionais, Rio de Janeiro, 1977, pp. 1-44.

Odebrecht, C., Garcia, V.M.T., 1997. Phytoplankton. In: Seeliger, U., Odebrecht, C., Castello, J.P. (Eds.), Subtropical Convergence Environments. The Coast and Sea in the Southwestern Atlantic. Springer, Berlin, pp. 105-109.

Odum, E.P., 1997. Ecology. A Bridge between Science and Society. Sinauer, MA, $330 \mathrm{pp}$.

Odum, W.E., Heald, E.J., 1975. The detritus-based food web of an estuarine mangrove community. In: Cronin, L.E. (Ed.), Estuarine Research, Vol. 1. Academic Press, New York, pp. 265-286.

Palomares, M.L.D., Pauly, D., 1989. A multiple regression model for predicting the food consumption of marine fish populations. Aust. J. Mar. Freshw. Res. 40, 259-273.

Patterson, K., 1992. Fisheries for small pelagic species: an empirical approach to management targets. Rev. Fish. Biol. Fish. 2, 321-338.

Pauly, D., Christensen, V., 1995. Primary production required to sustain global fisheries. Nature 374, 255-257.

Pauly, D., Soriano-Bartz, M.L., Palomares, M.L.D., 1993. Improved construction, parametrization and interpretation of steady-state ecosystem models. In: Christensen, V., Pauly, D.
(Eds.), Trophic Models of Aquatic Ecosystems. ICLARM Conference Proceedings 26, pp. 1-13.

Pauly, D., Christensen, V., Dalsgaard, J., Froese, R., Torres Jr., F., 1998. Fishing down marine food webs. Science 279, 860-863.

Peterson, I., Wroblewski, J.S., 1984. Mortality rate of fishes in the pelagic ecosystem. Can. J. Fish. Aquat. Sci. 41 (7), 1117-1120.

Rees, W.E., 1996. Revisiting carrying capacity: area-based indicators of sustainability. Population Environ. 17 (3), 195215.

Reis, E.G., Vieira, P.C., Duarte, W.S., 1994. Pesca artesanal de teleósteos no estuário da Lagoa dos Patos e costa do Rio Grande do Sul. Atlântica 16, 69-86.

Rice, J., 1995. Food web theory, marine food webs, and what climate changes may do to northern marine fish populations. In: Beamish, R.J. (Ed.), Climate Change and Northern Fish Populations, Vol. 121. Canadian Special Publication of Fisheries and Aquatic Sciences, pp. 561-568.

Rocha, G.R.A., Gasalla, M.A., Rossi-Wongtschowski, C.L.D.B., Soares, L.S.H., Pires-Vanin, A.M.S., Muto, E.Y., Cergole, M.C., Aidar, E., Mesquita, H.S.L., Gianesella-Galvão, S.M.F., Vega-Perez, L.A., Jarre-Teichmann, A., 1998. Quantitative model of trophic interactions in the Ubatuba shelf system (Southeastern Brazil). Naga, The ICLARM Quart., 25-32.

Rossi-Wongtschowski, C.L.D.B., Saccardo, S.A., Cergole, M.C., 1996. Are fluctuations in Brazilian sardine catches related to global-scale climate changes? Ann. Acad. Bras. Ci. 68 (Suppl. 1), 239-250.

Saccardo, S.A., 1980. Biologia e bionomia de Trachurus lathami (Nichols 1920) (Teleostei: Carangidae) na plataforma continental brasileira entre $23^{\circ} \mathrm{S}$ (RJ) e $30^{\circ} \mathrm{S}$ (RS). Ph.D. Thesis. University of São Paulo, Brazil.

Schwingel, P.R., Castello, J.P., 1995. Alimentación de la anchoita, Engraulis anchoita, en el sur de Brasil. Frente Maritmo (Montevideo) 15, 67-86.

Seeliger, U., Odebrecht, C., Castello, J.P. (Eds.), 1997. Subtropical Convergence Environments. The Coast and Sea in the Southwestern Atlantic. Springer, Berlin, 308 pp.

Soares, L.S.H., Rossi-Wongtschowski, C.L.D.B., Alvares, L.M.C., Muto, E.Y., Gasalla, M.A., 1992. Grupos tróficos de peixes demersais da plataforma continental interna de Ubatuba, Brasil. I. Chondrichthyes. Bolm Inst. Oceanogr. São Paulo 40 (1-2), $79-85$.

Steele, J.H., 1996. Regime shifts in fisheries management. Fish. Res. 25, 19-23.

Teixeira, C., Tundisi, J., 1967. Primary production and phytoplankton in equatorial waters. Bull. Mar. Sci. 17 (4), 884 891.

Trites, A.W., Livingston, P., Vasconcellos, M.C., Mackinson, S., Springer, A.M., Pauly, D., 1999. Ecosystem considerations and the limitations of ecosystem models in fisheries management: insights from the Bering Sea. In: Proceedings of the Symposium on the Ecosystem Effects of Fisheries, Anchorage, 1998.

Vaske Jr., T., 1992. Idade, crescimento e alimentação de albacora de lage, Thunnus albacares (Bonnaterre, 1788) (Perciformes: Scombridae), explorada no sul do Brasil. Master Thesis. University of Rio Grande, Brazil. 
Vazzoler, G., 1975. Distribuição da fauna de peixes demersais e ecologia dos Sciaenedae da plataforma continental brasileira entre as latitudes $29^{\circ} 21^{\prime} \mathrm{S}$ (Torres) e $34^{\circ} 44^{\prime} \mathrm{S}$ (Chui). Bolm Inst. Oceanogr. São Paulo 24, 85-169.

Vazzoler, A.E.A.M., Soares, L.S.H., Cunningham, P.T.M., 1999. Ictiofauna brasileira, Chap. 19. In: Lowe-MacConnel, R.H. Estudos Ecológicos de Communidades de Peixes Tropicais. EDUSP, São Paulo, Brasil. 535 p.

Vieira, P.J.C., 1990. Biologia populacional de Cynoscion striatus (Pisces: Scianidae) no litoral sul do Brasil. Master Thesis. University of Rio Grande, Brasil.

Vilela, M.J., 1990. Idade, crescimento, alimentação e avaliação do estoque de bonito listado (Katsuwonus pelamis) (Scombridae: Thunnini), explotado na região sudeste-sul do Brasil. Master Thesis. University of Rio Grande, Brazil.
Vyalov, Y.A., Ovchinnikov, V.V., 1980. Main results of the tuna, swordfish and sailfish studies in the Atlantic Research Institute for the Fisheries and Oceanography (Atlantniro) for the 20 year period (1957-1977). Collect. Vol. Sci. Pap. ICCAT Madrid 9 (3), 662-674.

Walsh, J.J., 1981. A carbon budget for overfishing off Peru. Nature 290, 300-304.

Walters, C., Christensen, V., Pauly, D., 1997. Structuring dynamic models of exploited ecosystems from trophic mass-balance models of marine ecosystems. Rev. Fish Biol. Fish. 7 (2), 139172.

Zavala-Camin, L.A., 1987. Ocorrência de peixes, cefalópodos e crustáceos em estômagos de atuns e espécies afins, capturadas com espinhel no Brasil (23-34 ${ }^{\circ}$ S) 1972-1985. Bolm Inst. Pesca São Paulo 14 (1), 93-102. 